\title{
Revisiting Insularity and Expansion: A Theory Note
}

\author{
John M. Schuessler, Joshua Shifrinson and David Blagden
}

\begin{abstract}
What is the relationship between insularity — a state's separation from other states via large bodies of water-and expansion? The received wisdom, prominent in (though not exclusive to) realist theories, holds that insularity constrains expansion by making conquest difficult. We contend, by contrast, that this received wisdom faces important limits. Focusing on U.S. expansion via means short of conquest, we interrogate the underlying theoretical logics to demonstrate that insular powers enjoy two distinct advantages when it comes to expansion. First, insularity translates into a "freedom to roam": because insular powers are less threatened at home, they can project more power and influence abroad. Second, insularity "sterilizes" power, which explains why insular powers are seen as attractive security providers and why we do not see more counterbalancing against them. On net, existing scholarship is correct to argue that insularity impedes conquest between great powers. Still, it has missed the ways that insularity abets expansion via spheres of influence abroad. One consequence is an under-appreciation for the role of geography writ large and insularity in particular in shaping contemporary great power behavior.
\end{abstract}

$\bigwedge^{\mathrm{h}}$ hat is the relationship between insularity-a state's separation from other states via large bodies of water-and great power politics? Insularity plays a major explanatory role in prominent international relations (IR) theories, particularly those emphasizing material and geopolitical factors as drivers

John Schuessler (1) is Associate Professor in the Department of International Affairs and Co-Director of the Albritton Center for Grand Strategy at the Bush School of Government and Public Service, Texas AorM University (jmschues@tamu. edu). He is the author of Deceit on the Road to War: Presidents, Politics, and American Democracy (Cornell University Press, 2015).

Joshua Shifrinson (1) is Associate Professor of International Relations at Boston University (jris@bu.edu). His research examines great power politics, international security, and U.S. foreign policy. A graduate of MIT, he is most recently the author of Rising Titans, Falling Giants: How Great Powers Exploit Power Shifts (Cornell University Press, 2018).

David Blagden (1) is Senior Lecturer at the University of Exeter's Strategy and Security Institute (D.W.Blagden@exeter.ac.uk). His research has been published in International Security, Security Studies, International Studies Quarterly, Survival, International Affairs, Foreign Policy Analysis, and International Studies Review, among other outlets. He obtained his DPhil at the University of Oxford. of state behavior (Jervis 1978; Mearsheimer 2014). Likewise, the issue is central to policy discussions over American grand strategy as analysts debate whether the United States can or should remain deeply engaged abroad (Posen 2014; Brooks and Wohlforth 2016; Van Hooft 2020). Despite its theoretical and policy salience, however, insularity's impact on international relations and, especially, great power politics remains undertheorized.

To the extent there is a received wisdom, scholars emphasize insularity's tendency to constrain great powers from expanding by inhibiting conquest, thereby limiting the intensity of competition between them (Layne 2002; Mearsheimer 2014; Ripsman, Taliaferro, and Lobell 2016). Broadly rooted in realist approaches to IR theory (though not exclusively; see Lake 1999, 46), this argument hinges on the difficulty of projecting military power across large bodies of water and, relatedly, the defensive advantages enjoyed by insular powers. Still, this line of reasoning faces empirical and theoretical limits. For one thing, claims of insularity's expansion-inhibiting nature have difficulty fully accounting for the behavior of insular powers: even without conquering other great powers, there are prominent cases of insular powers that have been quite expansionist. Most notably, the United States carved out spheres of influence in geopolitically vital areas such as Western Europe, East Asia, and the Middle East after World War II (Gaddis 1982; Leffler 1992; Trachtenberg 1999) that endure to this day (Silove 2016; Sayle 2019; Moller 2020).

Theoretically, meanwhile, the claim that insularity inhibits expansion is problematic. Path-breaking 
scholarship on hegemony (Ikenberry and Nexon 2019; Nexon and Neumann 2018), hierarchy (Lake 1999, 2009), imperialism (Go 2011; Nexon and Wright 2007) and order (Ikenberry 2011; Cooley and Nexon 2020) features great powers that have extended their political reach by constructing spheres of influence, establishing protectorates, and forming empires without resorting to conquest. The emphasis thus far, however, has been on the economic (Norrlof 2010), institutional (Ikenberry 2001; Goh 2007), and normative (Kupchan 2014) factors that help states craft superior-subordinate relations over others and shape the varied patterns of influence that result. Less work has been done evaluating geopolitical factors such as insularity that may enable expansion in the first place. This is important because previous studies of insularity have occasionally implied that it can offer great powers advantages - for example, in the form of reduced counterbalancing-that may plausibly facilitate expansion through non-conquest means (Walt 1987; Joffe 1997; Levy and Thompson 2010). Although no project has yet 1) distinguished among the mechanisms involved or 2) linked individual findings into a broader theory of insular advantages, the results again suggest that the received wisdom treating insularity as a constraint on expansion is incomplete.

Researchers are thus left with a puzzle. Some insular powers have expanded far and wide, and they have done so without engaging in the conquest of other great powers. With the logic linking insularity to non-expansion theoretically questionable, scholars lack an explanation for how and why insular powers have been able to grow their geopolitical footprint. The result is a gap in scholarship on the relationship between insularity and great power politics. Without claiming to develop a complete theory of insularity, we look to begin addressing the gap by examining the mechanisms and conditions by which insularity can facilitate great power expansion short of conquest.

We advance three claims. First, because existing studies of insularity have largely occurred within the realist tradition, they tend to understate the ways in which great powers expand by focusing too narrowly on conquest. Relaxing this assumption, we extend insights from research on hegemony, hierarchy, imperialism, and order to highlight that great powers can increase their geopolitical footprint by constructing spheres of influence- geographic areas in which great powers dominate others' strategic affairs (Lake 1999, 28-29; Lake 2009, 54; Jackson 2020). ${ }^{1}$ Second, insularity affects the opportunity structure a great power faces if it seeks to expand. On one level, insularity lowers the cost a great power pays to provide security for itself, freeing up and increasing the supply of resources that it can use to project power and influence abroad. Insular powers, in other words, are free to roam. At the same time, insularity makes a great power less threatening to other states than if it were located onshore. This explains why insular powers are often seen as attractive security providers and why there is not more counterbalancing against them.

Third, the onshore distribution of power plays a crucial role in mediating when insular powers are able to utilize these advantages and expand. All things being equal, insular powers are more likely to expand via spheres of influence when a given region is menaced by a potential hegemon, or divided among at least two competing great powers. Under such conditions, imperiled states seeking security are likely to invite an insular power onshore into a given region and seek to keep it engaged. Conversely, other distributions of power can either 1) inhibit insular power expansion entirely (if a region is dominated by a single great power) or 2) invite military conquest of non-great powers (if an area lacks a great power).

The implications of this argument are stark. At root, the received wisdom on insularity may have it backwards: far from being constrained, insular powers may be uniquely privileged in growing their geopolitical footprint. In turn, underscoring that insular powers can expand by crafting spheres of influence raises the possibility of better linking research emphasizing material and geopolitical factors with scholarship on the economic, institutional, and normative underpinnings of hierarchy and hegemonic order. Rather than existing as disparate bodies of work, each may complement the other. We expand on these points later.

The remainder of this article proceeds in several sections. Following this introduction, we review the literature on insularity and expansion. Second, we highlight the limits of the received wisdom. From there-third-we extend existing research on insularity's advantages by highlighting the ways in which insularity can facilitate expansion via spheres of influence. Fourth, we hypothesize the effect of the distribution of power on insular power expansion. Fifth, we apply this framework to the United States - the insular power par excellence - and show how the argument can help explain the course of American grand strategy. Finally, we discuss the implications of our argument for theory and policy, paying particular attention to how a richer understanding of insularity can contribute to IR theory and, especially, scholarship on hierarchy and hegemonic order.

\section{Insularity and Expansion}

In the context of great power politics, what is the relationship between insularity and expansion? We define insularity as being surrounded by water. An insular power would thus be the only great power on a large body of land that is surrounded on all sides by water. ${ }^{2}$ A continental power, on the other hand, would be a great power located on a large body of land that is also occupied by at least one other great power (Mearsheimer 2014, 126). ${ }^{3}$ We define expansion, in turn, as the extension of a state's territorial control or political influence (Gilpin 1981, 106). 
If there is a received wisdom on the link between insularity and expansion, it is that insularity constrains expansion, primarily by making the conquest of other great powers exceedingly difficult (Jervis 1978, 189; Taliaferro 2000, 139; Van Evera 1999, 121; Glaser and Kaufmann 1998, 58). This argument is most clearly developed in the realist tradition which, as a body of work emphasizing states' desire for power and security and the causal weight of material factors, has tended to be most attuned to the influence of geography in general and insularity in particular (for a partial exception, see Lake 1999, 44-46). In this vein, defensive realism finds that insularity influences the severity of the security dilemma between great powers by affecting their ability to attack and conquer one another (Taliaferro 2000: 136-41). Here, being surrounded by water particularly advantages the defense relative to the offense. Robert Jervis lays out the key elements of the argument in his treatment of the security dilemma, offering that, "Anything that increases the amount of ground the attacker has to cross, or impedes his progress across it, or makes him more vulnerable while crossing, increases the advantage accruing to the defense. When states are separated by barriers that produce these effects, the security dilemma is eased, since both can have forces adequate for defense without being able to attack." Large bodies of water such as oceans serve the same function in this respect: "Being hard to cross, they allow defense against superior numbers. The defender has merely to stay on his side of the barrier and so can utilize all the men he can bring up to it. The attacker's men, however, can cross only a few at a time, and they are very vulnerable when doing so." If all states were islands, each would thus be largely secure (Jervis 1978, 194-96; also Van Evera 1998, 19; Glaser and Kaufmann 1998, 64-66; Glaser 2010, 141).

Offensive realism converges with defensive realism on insularity's essential defense-dominance (Blagden, Levy, and Thompson 2011, 196). Here, the stopping power of water (Mearsheimer 2014, 114-128) - the limits that large bodies of water place on states' ability to project land power-inhibits insular powers from attacking great powers outside their regions. This explains why great powers can only aspire to regional hegemony despite the fact that they would be more powerful and secure as global hegemons. In doing so, insularity adds a defensive element to an international system otherwise primed for offense. Although less precise than either offensive or defensive realism, classical (Morgenthau 1963, 110-112) and neoclassical (Ripsman, Taliaferro, and Lobell 2016, 41-42) realism take a similar approach, suggesting that insularity limits the external threats that great powers face and so reduces their need to expand in kind. Meanwhile, scholars utilizing insights from existing discussions of insularity to explain particular strategies by individual great powers echo these claims. Josef Joffe, for instance, contends that insularity "granted Britain that rarest gift of inter-state politics: immunity from direct attack," pushing Britain to prefer "balancing [against great power threats] rather than conquest" (Joffe 1997, 102, 104). Similarly, Jennifer Lind argues that Japanese insularity reduced its fears of attack during the Cold War, leading it to underinvest in military power relative to its economic potential and forego efforts at overseas power projection (Lind 2004, 104, 117).

\section{Insularity and Expansion: The Limits of the Received Wisdom}

In sum, the received wisdom holds that insularity is a constraint on expansion. We contend, by contrast, that this received wisdom is incomplete. First and foremost, the claim that insularity constrains expansion has difficulty accounting for insular powers' behavior, with the United States' record of expansion since 1945 posing a particular challenge. After all, as the insular power par excellencesurrounded by oceans on two sides, with weak neighbors to the north and south-the United States should be among the least likely of great powers to expand abroad. In fact, just the opposite has occurred.

Since World War II, the United States has built what Geir Lundestad terms an "empire by invitation," projecting power overseas in geopolitically significant regions such as Western Europe, East Asia, and the Middle East (Lundestad 1999). The effort has gone beyond simply maintaining a diplomatic and military footprint to hedge against regional disturbances. Instead, the United States has worked to control and structure regional dynamics in accordance with American interests. To do so, it has deployed large military forces abroad, committed substantial sums of money to overseas operations, involved itself heavily in regional diplomatic and economic affairs, and even risked war against capable states such as the Soviet Union, Iraq, and China (Jaffe 1993; Trachtenberg 1999; Layne 2002; Lake 2008, 2009; Hoffman 2013; Brooks and Wohlforth 2016; Silove 2016; Cooley and Nexon 2020; Moller 2020). Equally telling, the United States has increased its overseas presence over time, as NATO's postCold War move into Eastern Europe and ongoing efforts to bolster the U.S. commitment in Asia illustrate (Sarotte 2019a; Lind 2014).

For sure, relatively little of the United States' effort involved conquest, with much of its overseas presence negotiated with continental actors. Still, if the idea that insularity constrains expansion is to mean anything, we would not expect the United States to retain such an extensive presence abroad over such a lengthy period. Nor has the effort been entirely cooperative, with the United States frequently coercing other major powers such as Britain, France, Germany, the Soviet Union, and China in order to advance its overseas interests, often risking military confrontation along the way (Woods 1990; Kingseed 1995; Trachtenberg 1999; Shifrinson 2018, chap. 5; 
Silove 2016; Campbell and Sullivan 2019). These efforts are again difficult to explain if insularity mostly promotes restraint.

Neither can insular expansion be dismissed as an American phenomenon, as other insular powers have acted similarly. During its zenith in the nineteenth century, for example, the United Kingdom possessed a sizable fraction of global economic and military capabilities, and unrivalled command of the seas (Singer, Bremer, and Stuckey 1973; Rodger 2006). As an insular power able to control its own moats, the received wisdom would predict British restraint vis-à-vis other great powers. Yet, while it is true that the United Kingdom never sought to conquer the major states of continental Eurasia, it nevertheless expanded at their expense through a variety of channels. Thus, Britain challenged Russian claims in Central Asia, asserted dominance over the Yokohama Treaty Port that the U.S. Navy had opened in Japan, preempted France by annexing Egypt to ensure access to the Suez Canal, and competed with France and Germany for colonies in Africa-even risking near-wars with each in the late 1800s and early 1900s (Porter and Low 1999). Likewise, Japan expanded its footprint throughout East Asia in the late nineteenth and early twentieth centuries, not conquering other great powers but frequently challenging their interests-culminating in war against Russia. Again, such efforts are puzzling if insularity is constraining. ${ }^{4}$

The record of insular power expansion also highlights a conceptual dilemma with existing research, in that current studies rely upon a circumscribed definition of what expansion entails. To date, scholars interested in insularity have tended to equate expansion with conquest, that is, one state forcibly seizing some or all of the territory held by another. This type of expansion is certainly importantindeed, it occupies a prominent place in European diplomatic history and IR theory. Still, it is not axiomatic that expansion is synonymous with conquest.

This point is captured in the literatures on hegemony, hierarchy, imperialism, and order. As scholars such as David Lake, John Ikenberry, and Daniel Nexon underscore, great powers have been able to structure and influence the policy choices of other actors while stopping short of conquest. This insight applies to the contemporary United States: in one recent treatment, Nexon and Alexander Cooley emphasize that "within broader international order we find an American hegemonic system ... within which the United States directly orders and takes leadership of economic, security, and political relations" (Cooley and Nexon 2020, 46; see also Lake 2009, 82). To be clear, this body of research largely sidesteps the geopolitical factors that may enable expansion in order to focus on the economic, institutional, and normative factors undergirding the formation of different kinds of ordered relationships. Indeed, to the extent insularity enters the equation, research in this vein seems to largely accept the received wisdom of insularity as a constraint on expansion (Lake 1999, 46). Still, the scholarly program as a whole clarifies that great powers can expand short of conquest by crafting spheres of influence-more or less formally defined geographic areas in which great powers dominate others' strategic affairs and, by extension, exclude outside actors from similar influence over the same space (Lake 1999, 28-29; Lake 2009, 54; Jackson 2020).

Of course, the nature of the political relationships that characterize spheres of influence can vary, with some spheres characterized by mutually beneficial leader-subordinate relationships (Lake 1993; Clark 2009a, 2009b) while others entail little more than strong states maintaining self-interested arrangements at the expense of the weak (Layne 2006). At the limit, spheres of influence can even evolve into arrangements affecting the domestic politics of subordinate actors (Lake 1999; Go 2011). Regardless of the form it takes, however, expansion via spheres of influence is still expansion, with the effort involving real costs and benefits for the sphere-builder.

In terms of costs, sphere-of-influence-building involves shaping others' choices via statecraft short of brute force. Hence, it can require states to extend diplomatic and security commitments, deploy troops, and provide economic aid while risking conflict with competitors opposed to their expansion. On the benefits side, spheres can provide states greater leverage over their international environments than would otherwise be the case by fostering military quiescence, economic remuneration, and diplomatic fealty from those in one's sphere. Given that conquest has become progressively less appealing (Schweller 2011; Fazal 2007) as weaponry has become more destructive (Mueller 1989), the economics of conquest less obvious, ${ }^{5}$ nationalism more pronounced (Roshwald 2000), and norms of territorial integrity more robust (Zacher 2001), ${ }^{6}$ non-conquest methods of expansion such as spheres of influence are poised to be particularly relevant for contemporary world politics.

\section{Insularity as Facilitator of Expansion}

In tandem, the empirical problem posed by insular powers' record of expansion and the theoretical problem in equating expansion with conquest suggest that existing scholarship linking insularity with non-expansion is incomplete. Rather than discard the received wisdom, we seek to reformulate and adapt its core insights. In the process, we draw on research implying that insular powers may enjoy advantages in great power politics-in particular, that insularity may facilitate power projection while reducing others' tendency to counterbalance. While this research is not focused on expansion as such, we extend its insights to specifically consider its implications for insular power expansion. 
Our starting premise is that although insularity cannot explain why great powers expand, it shapes their opportunity structure when they seek to expand. ${ }^{7}$ More specifically, insular powers - like other great powers — can face a mix of security and non-security motives to expand that vary across time and space (Glaser 2010; Grynaviski 2018; Shifrinson 2018). Yet, because insularity-as the received wisdom emphasizes - makes the conquest of other great powers difficult, ${ }^{8}$ insular powers are pushed to consider alternate ways of expanding. This is where spheres of influence come into play.

In turn, insularity provides great powers with two advantages in constructing spheres of influence. First, insular powers are free to roam: secure at home, they enjoy a margin of strategic error that allows them to focus on projecting power and influence abroad. Second, insular powers' geographic remove makes them attractive security partners for states located in geopolitically crowded neighborhoods, increasing the demand for their presence abroad. Each mechanism has been flagged in previous research, but their combined impact in terms of facilitating expansion via spheres of influence has been overlooked. We treat each in turn.

\section{Freedom to Roam}

First, insularity lowers the cost a great power pays to provide security for itself, thereby freeing up resources with which it can expand. The relatively stronger an insular power, meanwhile, the more resources it has to devote to expansion.? Insular powers can be usefully contrasted in this respect with continental powers, which must devote most of their strategic effort to competing with each other and are limited in their ability to pursue outside ambitions. ${ }^{10}$ Insular powers, in other words, are free to roam, which positions them well to project power and influence abroad.

Consider, again, the U.S. case. The fact that the U.S. homeland is surrounded by large bodies of water means that the risk of attack and invasion is minimal even in the face of hostile powers. This surplus of security gives the United States strategic flexibility, enabling it to project power abroad. As Mearsheimer puts it $(2014,365)$, "one of the main reasons the United States is able to station military forces all around the globe and intrude in the politics of virtually every region is that it faces no serious threats in the Western Hemisphere. If the United States had dangerous foes in its own backyard, it would be much less capable of roaming into distant regions." In other words, because the United States is an insular power, it can afford to be a global power (Layne 2006, 29).

Nor is the United States the only insular power to have benefitted from the freedom to roam. As Joffe (1995) and others underscore, Britain in its heyday could choose the extent to which it engaged in European great power squabbles, as well as entertain empire-building overseas, in good part because of the protection afforded by the English Channel. ${ }^{11}$ Similarly, Japan's ability to craft an Asian empire in the early twentieth century was helped by the fact that, as an archipelago, Japan could focus on power projection beyond its borders rather than defending itself at home. In fact, as Philip Streich and Jack Levy (2016) illustrate, Japan was sufficiently confident in its security by the early 1900s that it was even willing to compete with the much stronger Russian Empire for hegemony in East Asia.

Insular powers can be usefully contrasted with continental powers. To be sure, continental powers such as Imperial Spain, France, and Germany have sought to expand by developing forces for extra-regional power projection (Levy and Thompson 2010). When threatened by continental neighbors, however, or confronted by insular powers enjoying extra security, continental actors have been compelled to focus on territorial defense while sacrificing overseas power projection. Tellingly, for instance, Wilhelmine Germany was frustrated in its quest for world power by the resource demands of building a navy that could challenge Britain at sea and an army that could confront the Franco-Russian alliance on land (Murray 2010). Unable to afford both land and sea power, Germany was forced to focus on continental security. ${ }^{12} \mathrm{~A}$ rising China faces similar constraints today in breaking out of East Asia (Ross 2009; Montgomery 2014, 124-125).

The freedom to roam is not sacrosanct. Although insular powers enjoy significant security that can enable roaming, both the rise of a continental hegemon (Mearsheimer 2014) and development of technologies that facilitate power projection over water (Adams 2003/04, 58n41; Gompert 2013, 21-24) can reduce the protection afforded by insularity. Ceteris paribus, however, insular powers' baseline level of security is greater than that of their continental counterparts: it takes comparably large shifts in power or technological changes to affect their security relative to continental actors. Hence, as Barry Posen illustrates, France was forced to treat interwar Germany as a threat earlier than Britain, in part because France's border with Germany deprived it of the security enjoyed by the insular United Kingdom (Posen 1984, 105-16, 177). Similarly, the United States can remain broadly indifferent to great power politics in other regions unless a potential hegemon emerges that is poised to mobilize that region's resources against the United States (Mearsheimer 2014, 142).

\section{Sterilizing Effects of Insularity}

The freedom to roam is of limited utility if states in other regions are determined to keep the roaming state out. Here, however, the second advantage of insularity applies: insularity sterilizes the challenge posed by insular states' 
power, rendering it less threatening than if it were located next door. The logic here is simple. Although insular powers may have a large supply of resources to put toward expansion, it remains more difficult for them to conquer states that are separated from them by water than if those same states were neighbors (Mearsheimer 2014, 114-119; Posen 2002, 123). In this sense, insularity functions as a specific manifestation of the "loss of strength" gradient. As originally formulated, the loss of strength gradient captures the idea that states' ability to project power declines with distance (Boulding 1962, 230-31, 245-47). Extending this insight, Stephen Walt (1987, 23-24) proposed that states' proximity is a key component driving threat perceptions and balancing: the closer states are to one another, the more threatening they appear and the stronger the balancing response. ${ }^{13}$ Distance alone, however, fails to capture the impact of insularity. After all, France is physically closer to insular Britain than continental Germany, yet few would argue that French security policy before 1945 was more focused on Britain than Germany. Distance aside, the particular difficulty of projecting military power across water meaningfully reduces the threat offshore powers pose to those onshore.

The sterilizing effect of insularity has two consequences. First, it makes insular powers attractive security providers, increasing the demand for their onshore presence. All things being equal, states in geopolitically crowded neighborhoods should feel less menaced by insular powers than by their continental neighbors while simultaneously calculating that they can reap strategic advantages if they can gain insular powers on their side. ${ }^{14}$ Hence, insular powers should find themselves invited into key regions when threats to the onshore balance of power demand a counterweight. For sure, this trend is not absolute: by our logic, insular powers need enough power projection to provide security for others but not so much as to constitute an overwhelming threat themselves. Still, because insularity makes conquest difficult, this leaves a wide range of conditions in which insular powers are relatively less threatening to continental actors than their neighbors and so are viewed as attractive security partners.

Tellingly, for example, major powers outside the Western Hemisphere have sought U.S. help in regional competitions spanning the two world wars (Tucker 2007; Cull 1995), the Cold War (Sayle 2019), and the post-Cold War era (Sarotte 2009, 2019b). Likewise, British forces were welcomed ashore by continental partners to counter threats ranging from Hapsburg Spain and Napoleonic France, to Imperial/Nazi Germany and the Soviet Union (Steiner 1969; Howard 1972; Baylis 1984; Dockrill 2002). In fact, an alliance with an insular power can be a sufficiently valuable commodity that continental states are willing to make concessions that serve the insular power's interests rather than risk abandonment (Gerzhoy 2015; Schuessler and Shifrinson 2019); this gives insular powers leverage to restrain risky behavior by local partners (Pressman 2008; Fang, Johnson, and Leeds 2014). Simply put, insularity generates high demand for offshore powers as allies, which translates into bargaining advantages over those who want their protection.

Relatedly-second-insular powers face less counterbalancing than they otherwise might. When an insular power intervenes abroad to uphold the balance of power, it disadvantages continental states that were poised to overturn the balance absent the insular power's presence. Theoretically, these states face incentives to counterbalance the insular power. In practice, however, insularity mitigates the problem. Being offshore, the insular power poses less of a threat to such actors than if it were located onshore. Thus, even rivals have reason to discount arguments that the insular power challenges their security. At the same time, if and when counterbalancing does occur, the insular power can support continental actors directly threatened (because of their location onshore) by the balancing attempt. States seeking to counterbalance thereby have a difficult time doing so as they must first overcome local opposition facilitated by the insular power (similarly, see Wohlforth 1999, 28). Finally, if all else fails, the insular power can play to its strategic flexibility and retrench (MacDonald and Parent 2011). Retrenchment may not in itself eliminate counterbalancing, but it can limit its intensity by lowering threat perceptions and opening up space for reassurance (Stein 1991; Montgomery 2006). In fact, by retrenching-or threatening to retrench - the insular power may even convince rivals that it represents the lesser of two evils, with the alternative being a security competition with neighbors no longer restrained by the insular power. In this way, the insular power can garner grudging acceptance by rivals of the status quo, further moderating counterbalancing.

\section{Linking Insularity and the Onshore Distribution of Power to Expansion}

Combined, the freedom to roam and the sterilizing effect of insularity can facilitate insular power expansion via spheres of influence. On the one hand, the freedom to roam allows insular powers to devote resources to expansion abroad: secure at home, they are able to project power and influence beyond their borders. Meanwhile, insularity's sterilizing effect makes offshore powers less of a threat to continental powers than their neighbors. Hence, insular powers find themselves invited into other regions as security providers, gaining influence over continental states in the process. In tandem, these pathways create a space whereby insular powers are able to expand in ways short of conquest: they can leverage their extra resources and attractiveness as partners to gain access to other regions and cultivate spheres of influence. 
Still, insular powers' opportunity to expand by crafting spheres is not unlimited. Instead, we hypothesize that relative power-especially the onshore distribution of power in regions of interest-is likely to influence whether and when insular powers can play to their advantages and expand in the manner described. Put simply, the onshore distribution of power affects when insular powers are invited into a region, the influence they can exert there, and which (if any) states want them out. In turn, as the onshore distribution of power varies, so too does the capacity to create spheres of influence.

For the sake of theory development, we consider three distinct onshore distributions of power while holding an insular power's strength constant. First, an insular power might face a region dominated by a local hegemon. In this scenario, an insular power's ability to expand should be limited as the hegemon would aim to keep the insular power out; likewise, by virtue of the hegemon's dominating regional politics, we further expect the hegemon's neighbors to defer to its wishes. Reinforcing the situation, the insular power may be reluctant to expand in the first place as it may worry about the hegemon's meddling in its own backyard. ${ }^{15}$

Alternatively, consider onshore distributions of power that replicate what can be thought of as classic balance-ofpower situations: circumstances in which at least two great powers are struggling for security vis-à-vis one another. This set of conditions - which could encompass bipolar, balanced multipolar, and unbalanced multipolar systems - should be most conducive to insular power expansion via spheres of influence. On one level, competition among continental powers means that at least one of them is likely to seek assistance from an insular power that, because of the freedom to roam and difficulty of conquering other powers, can contribute to the onshore great power competition without overly threatening the players. Put simply, regional great power politics creates an opening for an insular power to move onshore. At the same time, the insular power is well positioned to demand concessions to its interests from any continental powers that seek its backing. In this way, it can exploit balance of power dynamics to expand onshore and form a sphere of influence.

This logic further implies that an insular power's space to expand via spheres of influence is likely to grow the more intensely that continental powers are threatened by their onshore peers. The presence or emergence of unbalanced multipolarity - where one continental great power looks poised to become a regional hegemon-seems especially favorable for insular power expansion. With relative power weighted in one continental state's favor, unbalanced multipolar environments are likely to create a large demand for an insular power's presence to offset the potential hegemon on the part of most or all other continental great powers threatened by domination.
Likewise, owing to the clear and pressing nature of the threat, one expects menaced states to be willing to accede to an insular power's demands. Combined, insular powers are poised to have multiple invitations onshore, significant bargaining leverage, and the possibility of creating a sphere of influence encompassing an array of continental great powers. That said, it follows that the potential hegemon would be especially focused on undermining the insular power's sphere of influence and pushing it offshore. Thus, it is no accident that the United States 1) built its "empire by invitation" following World War II when the Soviet Union loomed as a potential hegemon that local states sought to resist, and 2) was opposed by the Soviet Union. Likewise, it is unsurprising from this perspective that the American presence in Asia is currently growing as Japan and other regional states eye a rising China warily while China-as the only challenger for regional hegemony - is increasingly ambivalent over the United States' presence (Wuthnow 2018; Weiss 2019).

Finally, an insular power may face an onshore distribution without other great powers. In this scenario, an insular power is poised to face few obstacles to expansion of any kind. Indeed, even the received wisdom suggests that conquest might be feasible under such conditions as insular states that lack the capacity to conquer great powers might be sufficiently strong to dominate the relatively weak local actors involved. Local states may still invite insular powers onshore in order to gain their support in regional competitions, but - in practice-insular powers retain the option to expand either via spheres of influence or conquest as the imbalance of power in their favor reduces the costs of using force; either form of expansion would be possible. Similarly, the absence of other great powers may make it especially easy for insular powers to establish imperial relationships over local actors, whether formal empire as in the case of Britain in the nineteenth century or informal empire as in the case of the modern United States (Kohli 2020).

Overall, the feasibility of conquest in this scenario may help explain exceptions to the claim that insular powers expand through means other than conquest. For example, Japan built an overseas empire through conquest in the late nineteenth and early twentieth centuries. Consistent with our framework, Japan's primary gains came in the parts of Asia (Taiwan, Korea, and a fragmenting China) where other great powers were absent. ${ }^{16}$ Likewise, the relatively low cost of conquest absent other great powers might account for why Britain conquered large portions of Africa and Asia in the nineteenth century: although Britain confronted other great powers in the process, major conquests in Africa and Asia were predominantly at the expense of weak local actors rather than peer competitors (for details, see MacDonald 2014). 


\section{Insularity in Action: American Grand Strategy}

Without claiming to offer a complete theory of insular power expansion, we have thus far hypothesized why insular power expansion is possible without the direct conquest of other great powers, as well as the conditions under which such expansion may occur. ${ }^{17}$ To showcase the plausibility of our claims, it is worth briefly considering the application of the argument to the United States, the insular power par excellence. Here, our framework neatly ties together a number of themes that are usually emphasized separately in the literature on American grand strategy.

Ultimately, it is hard to argue that the United States has not been expansionist. As noted earlier, since 1945 it has cultivated spheres of influence in Western Europe, East Asia, and the Middle East. Admittedly, the scope and nature of these spheres have varied over time and space. Nevertheless, the United States has generally embraced extensive security commitments to the most capable states in these areas and deployed large military forces to bolster its commitments. The United States has also worked to shape relations among states in its orbit in ways that redound to its benefit while seeking to deter threats from actors outside these arrangements. Collectively, this all adds up to a preponderant American role in these regions (Leffler 1992; Layne 2006; Brooks and Wohlforth 2016), with even once-skeptical scholars referring to the United States as a global hegemon after the Cold War (Posen 2014; Mearsheimer 2018; Walt 2018).

The extent of this expansion presents a puzzle for the received wisdom, which has trouble explaining how and why an insular power such as the United States could successfully cultivate spheres of influence in several regions over a decades-long period. In contrast, our claim that insularity abets expansion through non-conquest means helps capture this trend. By our logic, insularity may not explain why the United States expands, but it neatly illuminates why the United States enjoys the capacity and opportunity to do so. In fact, several aspects of our argument are evident in postwar American grand strategy.

For one thing, the United States has enjoyed nearly unprecedented freedom to roam and has thus been able to invest extensively in power projection. During the Cold War, this involved forward-deployed forces in Europe and Asia to help deter Soviet aggression, alongside "expeditionary" forces suitable for rapid transport to global hotspots. Similarly, faced today with China's rise, strategists are recalibrating the United States' overseas presence, shifting military forces to Asia and acquiring capabilities optimized for power projection in the region (Hicks and Green 2016; Mitre 2018). Along the way, the decades-long American investment in power projection has yielded "command of the commons": the ability to unilaterally exploit the air, sea, and space domains while denying their use to others (Posen 2003). Simply put, insularity has enabled the United States to focus on overseas contingencies without imperiling security at home.

Second, and despite its investment in power projection, the United States has been readily invited onshore in other regions while gaining substantial influence over partners' foreign policies. One of the more striking features of American grand strategy has been the readiness with which other countries have sought out an American presence and encouraged U.S. inroads in their neighborhoods. Western European states, for instance, lobbied the United States to involve itself in European politics after World War II against the Soviet Union (Ireland 1981). After the Cold War, Eastern European states similarly called for NATO enlargement to gain the United States as an ally against Russia while Western European actors sought to keep the United States in the region to offset a newly reunified Germany (Goldgeier 1999; Sayle 2019; Sarotte 2019b). Similar trends occurred in Asia-as local powers such as Japan sought out an American commitment to offset the Soviet Union and China (Nye 1995; Samuels 2007) —and the Middle East — where states as varied as Israel, Iran, and Saudi Arabia have invited the United States into the region at different times to address local security problems (BarSiman-Tov, Hahn, and Schoenbaum 1998; Litwak 1984; Long 1985). Once committed, meanwhile, the United States has been able to influence local states' security policies by stymying partners' nuclear aspirations (Gavin 2015), shaping allied diplomatic and military policies (Trachtenberg 1999; Rapp-Hooper 2020), and blocking alternate security systems from forming (Zoellick 2011; Shifrinson 2020b). Along the way, states in the American orbit have worried that the United States would play to its insularity and abandon them, providing a potent source of U.S. bargaining leverage (Trachtenberg 1999; Schuessler and Shifrinson 2019). ${ }^{18}$ In sum, not only has the United States been invited into other regions - a finding consistent with our framework - but it has used this position to influence regional dynamics in a manner conducive to U.S. interests.

One might counter that the freedom to roam and invitations onshore simply reflect the United States' exceptional power. If so, then realist theories-as the body of literature most focused on the role of power in international politics-would lead us to expect significant counterbalancing: although bandwagoning occasionally occurs, states are generally expected to balance against powerful actors focused on projecting power beyond their borders. Yet, while some states, at some times, have attempted to check the United States, the scope of this counterbalancing has, as our argument predicts, been strikingly inconsistent. Equally important, the lack of balancing does not seem to be explained by the narrow 
range of situations - primarily where states are revisionist actors looking to gain for themselves (Schweller 1994) or so weak that defeat is inevitable (Labs 1992) — where one expects bandwagoning.

The Cold War, for example, certainly saw the Soviet Union balance against the United States. Yet, as Trachtenberg (1999) demonstrates, this behavior had important limits. Indeed, by the 1960 s, Soviet leaders sought to keep the United States engaged in European security rather than see the United States leave the continent. Nor was this just a temporary aberration, as Soviet strategists contemplating the end of the Cold War desired a continued American presence in Europe to hedge against a possible German threat. ${ }^{19}$ Western European states have exhibited parallel tendencies. Despite having the power potential by the mid-Cold War to challenge the United States, European counterbalancing was largely absent, as calls from the mid-1970s onward to bolster intra-European cooperation against the United States regularly faltered. As Timothy Sayle documents, states such as Britain, France, and West Germany preferred to bank on offshore American security guarantees rather than commit to trusting one another (or Russia) (Sayle 2019, ch. 7).

Asia witnessed similar trends. For example, post-Cold War East Asia initially saw both Japan and China bid to keep the United States engaged in the region despite concerns among analysts that one or both states might try to counter the United States (Christensen 1999). And, while it is true that China today is balancing the United States, it is worth noting the elements of consistency in Chinese strategy. Defense spending as a percentage of Chinese gross domestic product has remained steady; China has cultivated only a few weak allies; and much of Chinese military doctrine is geared more to defending against an American attack rather than pushing the United States out of East Asia (Fravel 2019; Shifrinson 2020a). In short, counterbalancing against the United States has been muted even on the part of capable actors - an outcome consistent with our logic.

\section{Conclusion}

To summarize, we explain why and how insularity can facilitate great power expansion rather than-as the received wisdom propose-inhibiting it. Insularity does so by 1) increasing the resources that insular powers can put toward power projection, and 2) rendering insular powers less threatening to others such that it increases the demand for their presence abroad. Depending on the onshore distribution of power, these advantages can translate into opportunities for insular powers to expand overseas by constructing spheres of influence.

Although not a full theory of insularity, our arguments carry implications for future research, theory, and policy. In terms of research, additional work is warranted to refine the causal mechanisms and expand on the conditions whereby insularity facilitates expansion. Here, examining a broader set of great powers beyond the postwar United States, nineteenth-century Britain and Imperial Japan would be of use, as would further work on American, British and Japanese expansion. It would also be valuable to assess the extent to which our claims extend to insular non-great powers such as Australia. Prima facie, it is suggestive that such states have taken leading roles in balancing prospective hegemons in their regions while deploying forces far from home (Middleton 2011; Packham 2020), but additional research is warranted.

For theory, meanwhile, this article foregrounds the need to re-examine the influence of insularity on international politics. One issue concerns the prevalence of great power expansion. If insularity facilitates expansion, then prominent arguments that insular powers are uniquely unlikely to grow their geopolitical footprint need reconsideration. Instead, the true distinctiveness of insular powers may come in their mode of expansion-cultivating spheres of influence instead of conquest - rather than their proclivity for it. If anything, our argument underscores that insular powers may be especially capable of growing their relative positions, rather than relying upon their inherent security and foregoing further efforts to accumulate power. This, in turn, directs attention to the importance of exploring whether and to what extent insular powers' capacity to expand without conquest also influences their motivations - a key arena for future theorizing on the broader effects of insularity.

Equally important, that insular power expansion can occur via spheres of influence raises the possibility of bringing scholarship on insularity into fuller conversation with research on hegemony, hierarchy, imperialism, and order. As noted, much of the latter literature emphasizes the economic, institutional, and normative underpinnings of different kinds of superior-subordinate relationships in international politics. ${ }^{20}$ Our work, in contrast, points to the possibility that certain great powers are able to expand without conquest largely because of where they are located irrespective of what they look like at home or the policies and values they embrace. It thus raises the question of whether and how much of the expansion featured in the hegemony and hierarchy scholarship can be accounted for by geopolitical variables.

As such, this project as a whole highlights the potential for linking an expanded appreciation for insularity (and geography in general) with insights from the hegemony and hierarchy literature in ways that may bolster both research programs. ${ }^{21}$ For example, it may be the case that each body of scholarship explains a portion of the expansion puzzle, with geopolitical variables helping to explain great powers' opportunity to expand, and research on hegemony and hierarchy capturing the content of the resulting relationships. To put it another way, there may be underexplored pathways by which great powers expand 
in manners similar to those discussed by hegemony and hierarchy scholars but enabled by factors related to geopolitics. In short, a renewed focus on insularity holds the possibility of uncovering new sources of great power influence in international politics in ways that can complement other research programs.

Above all, our claims carry policy implications at a time when American grand strategy is in flux (Lissner and Rapp-Hooper 2018). On one level, critics of American grand strategy contend that the United States is expansionist in large part because of domestic and ideational factors, with an entrenched foreign policy establishment (Porter 2018; Walt 2018; Ashford 2020) wedded to liberal ideology (Mearsheimer 2018) especially culpable. In contrast, our work implies that attributing U.S. expansion to domestic and ideational factors may be incomplete: because insularity can enable expansion, the sources of the United States' overseas presence may be broader than critics of contemporary policy allow. By extension, even the emergence of a new domestic consensus favoring a lessengaged American role abroad might not temper U.S. behavior - the freedom to roam and sterilizing effect of insularity might still tempt expansion.

At the same time, this project underscores that the United States is poised to retain significant flexibility in its grand strategy. In doing so, it challenges claims among proponents of prevailing policy that any retrenchment is likely to foreclose American options in the future by compromising alliance relationships and allowing competitors to fill the void. Such claims are widespread. Hal Brands, for example, claims that retrenchment "might tempt [U.S. allies] to acquiesce to, or bandwagon with, a rising China" and ease "China's ascent to regional hegemony" (Brands 2015, 21-22). Similarly, former National Security Advisor H.R. McMaster argues that "a reduction in U.S. support for allies and partners ... could result in a shift in the balance of power away from the United States" (McMaster 2020: 185), while Tom Wright alleges that retrenchment would "make it impossible for the United States to maintain a political alliance with the democratic world [as] countries would begin to give China the benefit of the doubt" on key issues and so leave the U.S. isolated (Wright 2020). Walk back American expansion now-so this reasoning goesand the United States will not be able to act abroad in the future.

Ultimately, our work challenges these concerns. Because demand for the United States as a security provider is likely to increase the more geopolitics in other regions are contested and divided, retrenchment may generate more calls for the United States to move onshore by increasing intra-regional tensions. Meanwhile, because the United States' freedom to roam will remain intact so long as American insularity endures, the United States will have the option of re-committing abroad as its interests dictate. In short, insularity provides the United States with structural advantages that afford it grand strategic latitude. Far from requiring a sustained presence overseas, the United States' geographic position allows it to grow its power and influence abroad at times and places of its choosing. In this, it is like other insular powers past and future.

\section{Acknowledgement}

The authors would like to thank the following for incisive contributions during this manuscript's long journey to publication: Tim Crawford, Jennifer Erickson, Brendan Green, Charles Glaser, Rosemary Kelanic, Kyle Lascurettes, Lindsey O'Rourke, Patrick Porter, Barry Posen, Robert Reardon, Evan Resnick and last, but certainly not least, the editors and anonymous reviewers at Perspectives on Politics. Audiences at George Washington, Notre Dame, and Texas A\&M all had a hand in shaping the manuscript as well. Our apologies to anyone we inadvertently left out.

\section{Notes}

1 Our use of sphere of influence subtly breaks from the use of the term in research on hegemony, hierarchy, imperialism, and order. The latter literature usefully suggests that expansion need not include conquest while distinguishing among the different kinds of arrangements - for example, spheres of influence, protectorates, informal empires, etc.- - that can emerge as great powers gain influence over others' foreign or domestic affairs. In contrast, we focus on how insularity enables great power expansion itself rather than the specific features of the resulting relationships. For the sake of theory development, we therefore simplify the outcome of interest to distinguish between expansion which occurs via "conquest," and that which occurs when great powers gain leverage over others' strategic affairs - what we generically term a "sphere of influence." Consistent with hegemony, hierarchy, imperialism, and order scholarship, this leaves open the possibility that other factors may explain the specifics of any resulting arrangement.

2 Following Monteiro 2014, 42-47, we define a "great power" as a state capable of defending itself against the most powerful states in the system while projecting sufficient power to threaten the interests of such states.

3 Extending this logic, a regional hegemon is an insular power as long as it does not share a landmass with another great power. The United States, for example, is both a regional hegemon and an insular power because it is the only great power in the Western Hemisphere.

4 We are not arguing that overseas expansion is solely an insular power phenomenon. Indeed, continental 
powers such as Imperial Spain, the Dutch Republic, France, and Germany have occasionally developed large maritime forces for power projection. Rather, our point is that expansion is especially puzzling for insular powers which, given their significant latent security, are thought to have fewer incentives for expansion than continental powers.

5 An ongoing debate in IR theory concerns whether conquest yields economic gains (Liberman 1996; Brooks 2005). For our purposes, it suffices to note that the economic utility of conquest is contestable: there is some possibility conquest does not pay, such that states seeking to expand face incentives to consider alternate routes to increase their influence.

6 In an important amendment, Dan Altman (2020) finds that the nature of territorial conquest has evolved over time, with fewer wars initiated to conquer whole states but regular use of faits accomplis to seize pieces of territory.

7 Of course, insular powers may also opt not to expand.

8 Hence, insular powers should stop short of expanding into the homelands of other great powers.

9 Research on unipolarity suggests a similar trend: because unipoles are, by definition, unconstrained by other great powers, they are able to widely project power and influence (Waltz 2000, 13; Jervis 2009, 197; Crawford 2003, Conclusion). Rather than claiming that only unipoles can so act, our argument extends the insight to highlight that insular powers can more generally act abroad with reduced external pressures: free from attack at home unless other great powers develop the capacity to project power over water, they can more readily focus on expansion. Note, too, that these issues may interact, with insularity abetting a state's rise to unipolarity in part by enabling expansion.

10 Relatedly, see Elman (2004) and Ross (2009). This is also why-contrary to earlier geopolitical thinkers' expectations (MacKinder 1904)—location within territorial Eurasia has not become a springboard for global hegemony.

11 See also Williamson 1969, Howard 1972, Friedberg 1988. This is consistent with Julian Corbett's 1918, 48 , argument that island powers enjoying control of the sea can choose to limit their involvement in any war they enter.

12 It did not help that Wilhelmine Germany was politically constrained from raising tax revenues to fund its naval buildup; D'Lugo and Rogowski 1993.

13 Similarly, Jack Levy and William Thompson 2010 argue that sea powers - many of which are insular states-elicit less counterbalancing than land powers because they are less territorially threatening and can provide public goods.

14 Walt 1987, 277, makes a version of this point in the U.S. context: "For the middle-level powers of Western
Europe and Asia, the United Sates is the perfect ally. Its aggregate power ensures that its voice will be heard and its actions will be felt .... At the same time, the United States is far enough away so as not to pose a significant threat."

15 Relatedly, see Elman 2004, 566.

16 In fact, the prospect of other great powers moving in helped trigger Japanese conquest to prevent other actors from hindering Japan's expansion; (Greve and Levy 2018; Streich and Levy 2016.

17 Again, we contend that insularity affects the opportunities states have to expand without necessarily causing them to exploit the opportunity. This distinction may help explain instances where, in contrast to the U.S. experience discussed later, insular powers opted not to craft spheres of influence. Indeed, such seeming discrepancies may be the exceptions that prove the general argument. Illustrative is Britain's reluctance to craft a European sphere of influence in the nineteenth and early twentieth centuries: consistent with our argument, several of Europe's continental powers sought to entice Britain into a more active role in continental security throughout the late 1800 s and early 1900s, just as a subset of British strategists expressed interest in developing the military forces to play a more assertive continental role (Millman 1965; Williamson 1969; Steiner 1977). In short, although no British sphere of influence formed, there are hints that insularity nevertheless afforded Britain the opportunity to expand had it wanted.

18 There is a downside to insularity in the context of U.S. overseas expansion: it has made reassurance more difficult (Blankenship 2020), leading at times to a strong focus on bolstering U.S. credibility in U.S. foreign policy.

19 As Soviet President Mikhail Gorbachev told Secretary of State James Baker in May 1990 when discussing post-Cold War European security, "I think that both in Europe and here in the Soviet Union we recognize the need for US presence;" Memorandum of Conversation, May 1, 1990, Mikhail Gorbachev, Eduard Shevardnadze, and James Baker, folder "Gorbachev (Dobrynin) Sensitive 1989-June 1990 [Copy Set] [2]," box 91127, Scowcroft Files, George Bush Presidential Library, College Station, Texas.

20 For a recent take on order that draws more heavily from material and power variables, however, see Lascurettes 2020.

21 Similarly, our findings on the advantages of insularity may carry implications for other research including that on international political economy. For example, insularity may inform why the United States, like Britain before it, is able to leverage its place in the global economy to exert political influence; Farrell and Newman 2019. 


\section{References}

Adams, Karen Ruth. 2003/04. "Attack and Conquer? International Anarchy and the Offense-DefenseDeterrence Balance." International Security 28(3): 45-83.

Altman, Dan. 2020. "The Evolution of Territorial Conquest After 1945 and the Limits of the Territorial Integrity Norm.” International Organization 74(3): 490-522.

Ashford, Emma. 2020. "Build a Better Blob.” Foreign Affairs, May 29. (https://www.foreignaffairs.com/ articles/2020-05-28/build-better-blob).

Bar-Siman-Tov, Y., P.L. Hahn, and D. Schoenbaum. 1998. "The United States and Israel since 1948: A 'Special Relationship'?” Diplomatic History 22(2): 231-62.

Baylis, John. 1984. "Britain, the Brussels Pact, and the Continental Commitment." International Affairs 60(4): 615-29.

Blagden, David W., Jack S. Levy, and William R. Thompson. 2011. "Sea Powers, Continental Powers, and Balancing Theory." International Security 36, no. 2: 190-202.

Blankenship, Brian. 2020. "Promises under Pressure: Statements of Reassurance in US Alliances." International Studies Quarterly 64(4): 1017-30.

Boulding, Kenneth E. 1962. Conflict and Defense: A General Theory. New York: Harper.

Brands, Hal. 2015. "Fools Rush Out? The Flawed Logic of Offshore Balancing.” Washington Quarterly 38(2): 7-28.

Brooks, Stephen G. 2005. Producing Security: Multinational Corporations, Globalization, and the Changing Calculus of Conflict. Princeton, NJ: Princeton University Press.

Brooks, Stephen G., and William C. Wohlforth. 2016. America Abroad: The United States' Global Role in the 21st Century. Oxford: Oxford University Press.

Campbell, Kurt M., and Jake Sullivan. 2019. "Competition without Catastrophe: How America Can Both Challenge and Coexist with China." Foreign Affairs 5:96-111.

Christensen, Thomas J. 1999. "China, the U.S.-Japan Alliance, and the Security Dilemma in East Asia." International Security 23(4): 49-80.

Clark, Ian. 2009a. "Towards an English School Theory of Hegemony." European Journal of International Relations 15(2): 203-28.

_ 2009b. "Bringing Hegemony Back In: The United States and International Order." International Affairs 85(1): 23-36.

Cooley, Alexander, and Daniel Nexon. 2020. Exit from Hegemony: The Unraveling of the American Global Order. Oxford, UK: Oxford University Press.
Corbett, Julian S. 1918. Some Principles of Maritime Strategy. 2nd ed. London: Longman.

Crawford, Timothy W. 2003. Pivotal Deterrence: ThirdParty Statecraft and the Pursuit of Peace. Ithaca, NY: Cornell University Press.

Cull, Nicholas J. 1995. Selling War: The British Propaganda Campaign against American "Neutrality" in World War II. Oxford: Oxford University Press.

D'Lugo, David, and Ronald Rogowski. 1993. "The Anglo-German Naval Race and Comparative Constitutional 'Fitness." In The Domestic Bases of Grand Strategy, ed. Richard Rosecrance and Arthur A. Stein, 65-95. Ithaca, NY: Cornell University Press.

Dockrill, Saki R. 2002. Britain's Retreat from East of Suez: The Choice Between Europe and the World? London: Palgrave Macmillan.

Elman, Colin. 2004. "Extending Offensive Realism: The Louisiana Purchase and America's Rise to Regional Hegemony." American Political Science Review 98(4): 563-76.

Fang, Songying, Jesse C. Johnson, and Brett Ashley Leeds. 2014. "To Concede or to Resist? The Restraining Effect of Military Alliances." International Organization 68(4): 775-809.

Farrell, Henry, and Abraham L. Newman. 2019. "Weaponized Interdependence: How Global Economic Networks Shape State Coercion." International Security 44(1): 42-79.

Fazal, Tanisha M. 2007. State Death: The Politics and Geography of Conquest, Occupation, and Annexation. Princeton, NJ: Princeton University Press.

Fravel, M. Taylor. 2019. Active Defense: China's Military Strategy since 1949. Princeton, NJ: Princeton University Press.

Friedberg, Aaron. 1988. The Weary Titan: Britain and the Experience of Relative Decline, 1895-1905. Princeton, NJ: Princeton University Press.

Gaddis, John L. 1982. Strategies of Containment: A Critical Appraisal of Postwar American National Security Policy. New York: Oxford University Press.

Gavin, Francis J. 2015. "Strategies of Inhibition: U.S. Grand Strategy, the Nuclear Revolution, and Nonproliferation." International Security 40(1): 9-46.

Gerzhoy, Gene. 2015. “Alliance Coercion and Nuclear Restraint: How the United States Thwarted West Germany's Nuclear Ambitions." International Security 39(4): 91-129.

Gilpin, Robert. 1981. War and Change in World Politics. Cambridge, UK: Cambridge University Press.

Glaser, Charles L. 2010. Rational Theory of International Politics. Princeton, NJ: Princeton University Press.

Glaser, Charles L., and Chaim Kaufmann. 1998. "What Is the Offense-Defense Balance and Can We Measure It?" International Security 22(4): 44-82. 
Go, Julian. 2011. Patterns of Empire: The British and American Empires, 1688 to the Present. New York: Cambridge University Press.

Goh, Evelyn. 2007. "Great Powers and Hierarchical Order in Southeast Asia: Analyzing Regional Security Strategies." International Security 32(3): 113-57.

Goldgeier, James M. 1999. Not Whether but When: The U.S. Decision to Enlarge NATO. Washington, DC: Brookings Institution Press.

Gompert, David C. 2013. Sea Power and American Interests in the Western Pacific. Santa Monica, CA: RAND Corporation.

Greve, Andrew Q., and Jack S. Levy. 2018. "Power Transitions, Status Dissatisfaction, and War: The SinoJapanese War of 1894-1895." Security Studies 27(1): 148-78.

Grynaviski, Eric. 2018. America's Middlemen: Power at the Edge of Empire. New York: Cambridge University Press.

Hicks, Kathleen, and Michael J. Green. 2016. "Revving Up the Rebalance to Asia." Center for Strategic and International Studies, 26 January. (http:// www.cogitasia.com/revving-up-the-rebalance-to-asia/).

Hoffman, Elizabeth Cobbs. 2013. American Umpire. Cambridge, MA: Harvard University Press.

Howard, Michael. 1972. The Continental Commitment: The Dilemma of British Defence Policy in the Era of the Two World Wars. London: Maurice Temple Smith.

Ikenberry, G. John. 2001. After Victory: Institutions, Strategic Restraint, and the Rebuilding of Order after Major Wars. Princeton, NJ: Princeton University Press. - 2011. Liberal Leviathan: The Origins, Crisis, and Transformation of the American World Order. Princeton, NJ: Princeton University Press.

Ikenberry, G. John, and Daniel H. Nexon. 2019. "Hegemony Studies 3.0: The Dynamics of Hegemonic Orders." Security Studies 28(3): 395-421.

Ireland, Timothy. 1981. Creating the Entangling Alliance. Westport, CT: Greenwood Press.

Jackson, Van. 2020. "Understanding Spheres of Influence in International Politics." European Journal of International Security 5(3): 255-73.

Jaffe, Lorna S. 1993. The Development of the Base Force, 1989-1992. Washington, DC: Joint History Office, Office of the Chairman of the Joint Chiefs of Staff.

Jervis, Robert. 1978. "Cooperation Under the Security Dilemma." World Politics 30(2): 167-214.

—. 2009. "Unipolarity: A Structural Perspective." World Politics 61(1): 188-213.

Joffe, Josef. 1995. “'Bismarck' or 'Britain'? Toward an American Grand Strategy after Bipolarity." International Security 19(4): 94-117.

—. 1997. "How America Does It." Foreign Affairs 76 (5): $16-18$
Kingseed, Cole Christian. 1995. Eisenhower and the Suez Crisis of 1956. Baton Rouge, LA: Louisiana State University Press.

Kohli, Atul. 2020. Imperialism and the Developing World: How Britain and the United States Shaped the Global Periphery (Oxford, UK: Oxford University Press, 2020).

Kupchan, Charles A. 2014. "The Normative Foundations of Hegemony and the Coming Challenge to Pax Americana." Security Studies 23(2): 219-57.

Labs, Eric J. 1992. "Do Weak States Bandwagon?" Security Studies 1(3) 383-416.

Lake, David A. 1993. "Leadership, Hegemony, and the International Economy: Naked Emperor or Tattered Monarch with Potential?" International Studies Quarterly 37(4): 459-89.

- 1999. Entangling Relations: American Foreign Policy in Its Century. Princeton, NJ: Princeton University Press.

- 2008. "The New American Empire?" International Studies Perspectives 9(3): 281-89.

- 2009. Hierarchy in International Relations. Ithaca, NY: Cornell University Press.

Lascurettes, Kyle M. 2020. Orders of Exclusion: Great Powers and the Strategic Sources of Foundational Rules in International Relations. New York: Oxford University Press.

Layne, Christopher. 2002. "The 'Poster Child for Offensive Realism': America as a Global Hegemon." Security Studies 12(2): 120-64.

- 2006. The Peace of Illusions: American Grand Strategy from 1940 to the Present. Ithaca, NY: Cornell University Press.

Leffler, Melvyn. 1992. A Preponderance of Power: National Security, the Truman Administration, and the Cold War. Stanford, CA: Stanford University Press.

Levy, Jack S., and William R. Thompson. 2010.

"Balancing on Land and at Sea: Do States Ally against the Leading Global Power?” International Security 35(1): 7-43.

Liberman, Peter. 1996. Does Conquest Pay? The Exploitation of Occupied Industrial Societies. Princeton, NJ: Princeton University Press.

Lind, Jennifer M. 2004. "Pacifism or Passing the Buck? Testing Theories of Japanese Security Policy." International Security 29(1): 92-121.

—. 2014. "Pivot Problems." Foreign Affairs, 25 June. (https://www.foreignaffairs.com/articles/china/201406-25/pivot-problems).

Lissner, Rebecca Friedman, and Mira Rapp-Hooper. 2018. "The Day After Trump: American Strategy for a New International Order." Washington Quarterly 41(1): 7-25. 
Litwak, Robert. 1984. Détente and the Nixon Doctrine: American Foreign Policy and the Pursuit of Stability, 1969-1976. Cambridge: Cambridge University Press.

Long, David E. 1985. The United States and Saudi Arabia: Ambivalent Allies. Abingdon: Routledge.

Lundestad, Geir. 1999. "'Empire by Invitation' in the American Century.” Diplomatic History 23(2): 189-217.

MacDonald, Paul. 2014. Networks of Domination: The Social Foundations of Peripheral Conquest in

International Politics. Oxford: Oxford University Press.

MacDonald, Paul K., and Joseph M. Parent. 2011. "Graceful Decline? The Surprising Success of Great Power Retrenchment." International Security 35(4): 7-44.

MacKinder, Halford J. 1904. "The Geographical Pivot of History." Geographical Journal 23(4): 421-37.

McMaster, H.R. 2020. "The Retrenchment Syndrome." Foreign Affairs 99(4): 183-86.

Mearsheimer, John J. 2014. The Tragedy of Great Power Politics. New York: W.W. Norton and Company.

- 2018. The Great Delusion: Liberal Dreams and International Realities. New Haven, CT: Yale University Press.

Middleton, Karen. 2011. An Unwinnable War: Australia in Afghanistan. Carlton Victoria: Melbourne University Publishing.

Millman, Richard. 1965. British Foreign Policy and the Coming of the Franco-Prussian War. New York: Clarendon.

Mitre, Jim. 2018. "A Eulogy for the Two-War Construct." Washington Quarterly 41(4): 7-30.

Moller, Sarah Bjerg. 2020. “Twenty Years After: Assessing the Consequences of Enlargement for the NATO Military Alliance." International Politics 57(3): 509-29.

Monteiro, Nuno P. 2014. Theory of Unipolar Politics. Cambridge: Cambridge University Press.

Montgomery, Evan Braden. 2006. "Breaking Out of the Security Dilemma: Realism, Reassurance, and the Problem of Uncertainty." International Security 31(1): 151-85.

- 2014. "Contested Primacy in the Western Pacific: China's Rise and the Future of U.S. Power Projection." International Security 38(4): 115-49.

Morgenthau, Hans. 1963. Politics among Nations. 3rd ed. New York: Knopf.

Mueller, John E. 1989. Retreat from Doomsday: The Obsolescence of Major War. New York: Basic Books.

Murray, Michelle. 2010. "Identity, Insecurity, and Great Power Politics: The Tragedy of German Naval Ambition before the First World War." Security Studies 19(4): 656-88.

Nexon, Daniel H., and Iver B. Neumann. 2018. "Hegemonic-Order Theory: A Field-Theoretic
Account." European Journal of International Relations 24(3): 662-86.

Nexon, Daniel H., and Thomas Wright. 2007. "What's at Stake in the American Empire Debate?" American Political Science Review 101, no. 2: 253-271.

Norrlof, Carla. 2010. America's Global Advantage: US Hegemony and International Cooperation. Cambridge: Cambridge University Press.

Nye, Joseph S. 1995. "The Case for Deep Engagement." Foreign Affairs 74(4): 90-102.

Packham, Colin. 2020. "With Eyes on Indo-Pacific, Australia to Rapidly Increase Defence Spending."

Reuters, 30 June. (https://www.reuters.com/article/ukaustralia-defence/with-eyes-on-indo-pacific-australiato-rapidly-increase-defence-spendingidUKKBN24120P? edition-redirect=uk).

Porter, Andrew, and Alaine Low (eds.). 1999. The Oxford History of the British Empire, Volume III: The Nineteenth Century. Oxford: Oxford University Press.

Porter, Patrick. 2018. "Why America's Grand Strategy Has Not Changed: Power, Habit, and the U.S. Foreign Policy Establishment." International Security 42(4): 9-46.

Posen, Barry R. 1984. The Sources of Military Doctrine: France, Britain, and Germany Between the World Wars. Ithaca, NY: Cornell University Press.

- 2002. "The Best Defense." National Interest 67: 119-26.

— 2003. "Command of the Commons: The Military Foundation of U.S. Hegemony." International Security 28(1): 5-46.

- 2014. Restraint: A New Foundation for U.S. Grand Strategy. Ithaca, NY: Cornell University Press.

Pressman, Jeremy. 2008. Warring Friends: Alliance Restraint in International Politics. Ithaca, NY: Cornell University Press.

Rapp-Hooper, Mira. 2020. Shields of the Republic: The Triumph and Peril of America's Alliances. Cambridge, MA: Harvard University Press.

Ripsman, Norrin M., Jeffrey W. Taliaferro, and Steven E. Lobell. 2016. Neoclassical Realist Theory of International Politics. Oxford: Oxford University Press.

Rodger, N.A.M. 2006. The Command of the Ocean: A Naval History of Britain, 1649-1815. London: Penguin.

Roshwald, Ariel. 2000. Ethnic Nationalism and the Fall of Empires: Central Europe, the Middle East and Russia, 1914-23. New York: Routledge.

Ross, Robert S. 2009. "China's Naval Nationalism: Sources, Prospects, and the U.S. Response." International Security 34(2): 46-81.

Samuels, Richard J. 2007. Securing Japan: Tokyo's Grand Strategy and the Future of East Asia. Ithaca, NY: Cornell University Press. 
Sarotte, Mary Elise. 2009. 1989: The Struggle to Create Post-Cold War Europe. Princeton, NJ: Princeton University Press.

_. 2019a. "The Convincing Call from Central Europe: Let Us Into NATO.” Foreign Affairs, March 12 (https:// www.foreignaffairs.com/articles/2019-03-12/ convincing-call-central-europe-let-us-nato).

— . 2019b. "How to Enlarge NATO: The Debate inside the Clinton Administration, 1993-95." International Security 44(1): 7-41.

Sayle, Timothy. 2019. Enduring Alliance: A History of NATO and the Postwar Global Order. Ithaca, NY: Cornell University Press.

Schuessler, John M., and Joshua R. Shifrinson. 2019. "The Shadow of Exit from NATO." Strategic Studies Quarterly 13(3): 38-51.

Schweller, Randall. 1994. "Bandwagoning for Profit: Bringing the Revisionist State Back In." International Security 19(1): 72-107.

— . 2011. "Rational Theory for a Bygone Era." Security Studies 20(3): 460-68.

Shifrinson, Joshua R. Itzkowitz. 2018. Rising Titans, Falling Giants: How Great Powers Exploit Power Shifts. Ithaca, NY: Cornell University Press.

— . 2020a. "The Rise of China, Balance of Power Theory and US National Security: Reasons for Optimism?" Journal of Strategic Studies 43(2): 175-216.

- 2020b. "Eastbound and Down: The United States, NATO Enlargement, and Suppressing the Soviet and Western European Alternatives, 1990-1992." Journal of Strategic Studies 43(6-7): 816-46.

Silove, Nina. 2016. "The Pivot before the Pivot: U.S. Strategy to Preserve the Power Balance in Asia." International Security 40(4): 45-88.

Singer, J. David, Stuart Bremer, and John Stuckey. 1973. "Capability Distribution, Uncertainty, and Major Power War, 1820-1965." In Peace, War, and Numbers, ed. Bruce Russett, 19-48. Beverly Hills, CA: Sage.

Stein, Janice Gross. 1991. "Reassurance in International Conflict Management." Political Science Quarterly 106(3): 431-51.

Steiner, Zara S. 1969. The Foreign Office and Foreign Policy, 1898-1914. Cambridge: Cambridge University Press.

- Britain and the Origins of the First World War. New York: St. Martin's Press.

Streich, Philip, and Jack S. Levy. 2016. "Information, Commitment, and the Russo-Japanese War of 19041905.” Foreign Policy Analysis 12(4): 489-511.
Taliaferro, Jeffrey W. 2000. "Security Seeking under Anarchy: Defensive Realism Revisited." International Security 25(3): 128-61.

Trachtenberg, Marc. 1999. A Constructed Peace: The Making of the European Settlement, 1945-1963. Princeton, NJ: Princeton University Press.

Tucker, Robert W. 2007. Woodrow Wilson and the Great War: Reconsidering America's Neutrality, 1914-1917. Charlottesville: University of Virginia Press.

Van Evera, Stephen. 1998. "Offense, Defense, and the Causes of War." International Security 22(4): 5-43.

- 1999. Causes of War: Power and the Roots of Conflict. Ithaca, NY: Cornell University Press.

Van Hooft, Paul. 2020. "All-In or All-Out: Why Insularity Pushes and Pulls American Grand Strategy to Extremes." Security Studies 29(4): 701-29.

Walt, Stephen M. 1987. The Origins of Alliances. Ithaca, NY: Cornell University Press.

- 2018. The Hell of Good Intentions: America's Foreign Policy Elite and the Decline of U.S. Primacy. New York: Farrar, Straus and Giroux.

Waltz, Kenneth N. 2000. "Structural Realism after the Cold War.” International Security 25(1): 5-41.

Weiss, Jessica Chen. 2019. "How Hawkish Is the Chinese Public? Another Look at 'Rising Nationalism' and Chinese Foreign Policy." Journal of Contemporary China 28(119): 679-95.

Williamson, Samuel R. 1969. The Politics of Grand Strategy: Britain and France Prepare for War, 1904-1914. Cambridge, MA: Harvard University Press. Wohlforth, William C. 1999. "The Stability of a Unipolar World." International Security 24(1): 5-41.

Woods, Randall. 1990. A Changing of the Guard: AngloAmerican Relations, 1941-1946. Chapel Hill: University of North Carolina Press.

Wright, Thomas. 2020. "The Folly of Retrenchment." Foreign Affairs 99(2): 10-18.

Wuthnow, Joel. 2018. "Asian Security without the United States? Examining China's Security Strategy in Maritime and Continental Asia." Asian Security 14(3): 233-45.

Zacher, Mark W. 2001. "The Territorial Integrity Norm: International Boundaries and the Use of Force." International Organization 55(2): 215-50.

Zoellick, Robert B. 2011. "An Architecture of U.S. Strategy after the Cold War.” In In Uncertain Times: American Foreign Policy After the Berlin Wall and 9/11, ed. Melvyn P. Leffler and Jeffrey Legro, 26-43. Ithaca, NY: Cornell University Press. 